\title{
Identifying knowledge gaps about health and nutrition among rural pregnant mothers from 2 districts of Gujarat
}

\author{
Hemangini Gandhi ${ }^{1 *}$, Mousami Shah ${ }^{2}$ \\ ${ }^{\mathbf{1}}$ Assistant Professor, ${ }^{2}$ Research Coordinator, ${ }^{1}$ Dept. of Foods and Nutrition, ${ }^{\mathbf{1}-\mathbf{2}}$ The Maharaja SayajiRao University of Baroda, Vadodara, \\ Gujarat, India
}

*Corresponding Author: Hemangini Gandhi

Email: hgandhi1950@gmail.com

\begin{abstract}
Introduction: Encouraging healthy life style and dietary practices creates an impact not only on the child's long-term health, but potentially the mother's as well.

Objectives: The study was planned to assess the Knowledge about various aspects of Maternal and Child health to plan appropriate counseling material.

Materials and Methods: After informed consent, 100 pregnant women from 4 PHCS of Vadodara rural block and fifty from 1 PHC of Anklav block of Anand District were enrolled for the study. Information on knowledge regarding various aspects of health ad nutrition was elicited using pretested semi structure questionnaire.

Findings: It was found that only half of the pregnant women knew about the concept of healthy diet in both the groups. Knowledge about the correct weight gain during pregnancy was better in mothers from Anand (74\%) as compared to 47\% in Mothers from Vadodara. Ninety percent of pregnant women in Anand group had correct knowledge of giving colostrum to new born as compared to $71 \%$ in Vadodara group. Knowledge about anemia and contraceptive methods was also not satisfactory in both the group of pregnant mothers.

Conclusion: It can be concluded that knowledge regarding various aspects of health and nutrition requires frequent reinforcement using different strategies for sustainable development related to maternal and child health under various government programmes.
\end{abstract}

Keywords: Knowledge, Anemia, Colostrum, Pregnant mothers.

\section{Introduction}

Pregnancy is a critical time of human development, and anything that comprises the fetal environment may have important and lasting effects on the child's future health. It is important as a society to prioritize helping women understand the impact that their lifestyle and dietary choices have on their children. Maximizing the health of the pregnant mother will ensure her child the best start at life possible. Nutrition is a vital component of foetal development. Limiting exposure to damaging substances such as nicotine, caffeine, food-borne bacteria and alcohol will aid in the child's development. Helping women deal with unpleasant side effects of pregnancy as well as more serious ones should be a focus of prenatal support. Encouraging healthy lifestyle practices such as moderate physical activity and healthy dietary practices adhering to the recommended dietary allowances will create an impact not only on the child's long-term health, but potentially the mother's as well.. A good start in life is important and maternal nutritional status during pregnancy has repeatedly been demonstrated to be associated with pregnancy outcomes for the infant.

Continuum of care throughout pregnancy, birth, and after delivery has become a key program strategy for improving the health of mothers and new borns. Successful program implementation to improve the continuum of care relies on a better understanding of where the gaps are in seeking care along the pathway and what factors contribute to the gaps.

In recent time, even NITI AYOUG recommends promotion of healthy home diets for which people need to have correct knowledge about the same.

\section{Materials and Methods}

The study was planned to assess the Knowledge about various aspects of Maternal and Child health like importance of nutrition during pregnancy, Knowledge on correct IYCF practices, Anemia and Family planning method, of nutritionally high risk pregnant women. Women from four Primary Health Centres of Vadodara district and one Primary Health Centre of Anand district were enrolled.

The study was approved under the Department Of Medical Ethics Committee (No.F.C.Sc/IECHR/12). The Maharaja SayajiRao University of Baroda, Vadodara.

\section{Enrollment of the Subjects}

There are total 8 blocks in Vadodara district. Out of 8 blocks, One block- Dabhoi was purposively selected. Out of 3 blocks of Anand district Anklav block was purposively selected.

Before enrolling, mother's informed consent was obtained. In all 150 mothers were enrolled. 100 mothers from Dabhoi and 50 mothers from Anklav block formed the study sample. Information was collected using Pre tested questionnaire on Knowledge and Perception about Importance of nutrition during pregnancy, Correct IYCF practices, Consequences of Anemia, and Family planning.

\section{Results and Discussion}

Knowledge about selected aspects of maternal and child health 
Data on knowledge and perception about Importance of nutrition during pregnancy, Correct IYCF practices,
Consequences of Anemia, Family planning methodis presented in Table 1

Table 1: Importance of nutrition during pregnancy

\begin{tabular}{|c|c|c|c|c|c|}
\hline \multicolumn{2}{|c|}{ Particulars } & \multicolumn{2}{|c|}{ Dabhoi $\mathbf{N}=100$} & \multicolumn{2}{|c|}{ Anklav N=50 } \\
\hline & & \multirow{2}{*}{$\begin{array}{c}\mathrm{n} \\
52\end{array}$} & \multirow{2}{*}{$\frac{\%}{52 \%}$} & \multirow{2}{*}{$\begin{array}{c}\mathrm{n} \\
32\end{array}$} & \multirow{2}{*}{$\frac{\%}{64 \%}$} \\
\hline Concept of healthy diet & Correct answer & & & & \\
\hline & Partially Correct answer & 41 & $41 \%$ & 18 & $36 \%$ \\
\hline & Don’t know & 7 & $7 \%$ & 0 & $0 \%$ \\
\hline \multirow{5}{*}{$\begin{array}{l}\text { Kind of food consumed during } \\
\text { pregnancy }\end{array}$} & All 5 food groups & 42 & $42 \%$ & 15 & $30 \%$ \\
\hline & Only Avoiding Jaggery & 38 & $38 \%$ & 22 & $44 \%$ \\
\hline & Only Avoiding Ghee & 2 & $2 \%$ & 3 & $6 \%$ \\
\hline & Only Avoiding Milk & 3 & $3 \%$ & 0 & $0 \%$ \\
\hline & Avoiding both Milk and Jaggery & 15 & $15 \%$ & 10 & $20 \%$ \\
\hline \multirow{2}{*}{$\begin{array}{c}\text { Pregnant women should eat } \\
\text { more }\end{array}$} & Yes & 92 & $92 \%$ & 49 & $98 \%$ \\
\hline & No & 8 & $8 \%$ & 1 & $2 \%$ \\
\hline \multirow[t]{4}{*}{ If yes, how many times } & One and half times & 31 & $31 \%$ & 14 & $28 \%$ \\
\hline & Whenever one feels hungry & 61 & $61 \%$ & 15 & $30 \%$ \\
\hline & Any other & 0 & $0 \%$ & 20 & $40 \%$ \\
\hline & Not applicable & 8 & $8 \%$ & 1 & $2 \%$ \\
\hline \multirow{6}{*}{$\begin{array}{l}\text { Reason for eating more during } \\
\text { pregnancy }\end{array}$} & For normal healthy child & 19 & $19 \%$ & 14 & $28 \%$ \\
\hline & mother and child weight will increase & 45 & $45 \%$ & 3 & $6 \%$ \\
\hline & For normal delivery & 5 & $5 \%$ & 2 & $4 \%$ \\
\hline & $\begin{array}{l}\text { For normal healthy child and normal } \\
\text { delivery of mother }\end{array}$ & 2 & $2 \%$ & 0 & $0 \%$ \\
\hline & Any other & 23 & $23 \%$ & 29 & $58 \%$ \\
\hline & Don't know & 6 & $6 \%$ & 2 & $4 \%$ \\
\hline \multirow{3}{*}{ Normal weight of new born } & $2.5 \mathrm{~kg}$ & 31 & $31 \%$ & 28 & $56 \%$ \\
\hline & Any other $(<2.5 \mathrm{~kg}, 3 \mathrm{~kg})$ & 43 & $43 \%$ & 21 & $42 \%$ \\
\hline & Don't know & 26 & $26 \%$ & 1 & $2 \%$ \\
\hline \multirow[t]{3}{*}{ Weight gain during pregnancy } & $10-12 \mathrm{~kg}$ & 47 & $47 \%$ & 36 & $72 \%$ \\
\hline & Any other & 22 & $22 \%$ & 4 & $8 \%$ \\
\hline & Don't know & 31 & $31 \%$ & 10 & $20 \%$ \\
\hline
\end{tabular}

Data shown in table 1.1 revealed that only half of the pregnant women knew the concept of healthy diet in both the groups. Nearly $40 \%$ of the pregnant women in both the group opined about Jaggery to be avoided during pregnancy. The women's who told to avoiding certain items were due to misconception of having miscarriage or abortion (Garampade)(balakpadijaaye).Majority of the women knew about eating more during pregnancy. With regard to reason to eat more during pregnancy $45 \%$ of pregnant women in Dabhoi group could answer correctly so as only $6 \%$ of women in Anklav group.

Knowledge about the ideal weight of new born was said correct by $31 \%$ in Dabhoi group as compared to $56 \%$ in Anklav group (Fig.1) Knowledge about the weight gain during pregnancy among women was better and correct (10-12kg) in Anklav group (74\%) and $47 \%$ in Dabhoi group.

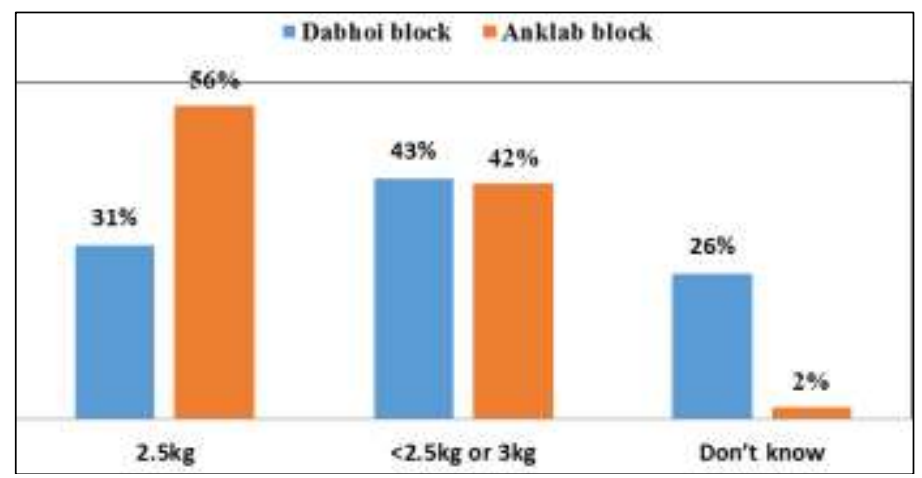

Fig. 1: Knowledge about normal weight of new born. 


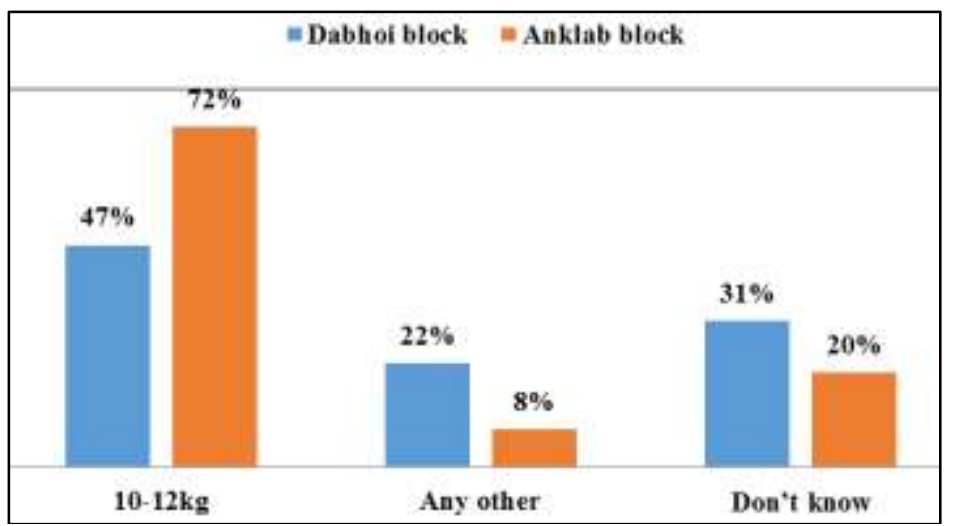

Fig. 2 Knowledge about weight gain during pregnancy

Knowledge about correct IYCF Practices were obtained which is presented in Table 2 and Fig. 3

Table 2: Knowledge about Correct IYCF practices

\begin{tabular}{|c|c|c|c|c|c|}
\hline \multirow{2}{*}{\multicolumn{2}{|c|}{ Particulars }} & \multicolumn{2}{|c|}{ Dabhoi N=100 } & \multicolumn{2}{|c|}{ Anklav N=50 } \\
\hline & & $\mathrm{n}$ & $\%$ & $\mathrm{n}$ & $\%$ \\
\hline \multirow{4}{*}{$\begin{array}{l}\text { Early initiation of Breast- } \\
\text { feeding }\end{array}$} & Immediately after birth & 52 & $52 \%$ & 11 & $22 \%$ \\
\hline & $<30$ mins after birth & 30 & $30 \%$ & 24 & $48 \%$ \\
\hline & Same day & 2 & $2 \%$ & 2 & $4 \%$ \\
\hline & Don’t know & 16 & $16 \%$ & 13 & $26 \%$ \\
\hline \multirow[t]{4}{*}{ First fed to Child After birth } & Mothers milk & 83 & $83 \%$ & 49 & $98 \%$ \\
\hline & Water & 4 & $4 \%$ & 1 & $2 \%$ \\
\hline & Jaggery/water & 2 & $2 \%$ & 0 & $0 \%$ \\
\hline & Don't know & 11 & $11 \%$ & 0 & $0 \%$ \\
\hline \multirow[t]{3}{*}{ Colostrum feeding } & Yes & 71 & $71 \%$ & 45 & $90 \%$ \\
\hline & No & 8 & $8 \%$ & 4 & $8 \%$ \\
\hline & Don’t know & 21 & $21 \%$ & 1 & $2 \%$ \\
\hline \multirow[t]{6}{*}{ If yes, Why } & Improving child's immunity & 32 & $32 \%$ & 6 & $12 \%$ \\
\hline & Makes child's healthy & 29 & $29 \%$ & 33 & $66 \%$ \\
\hline & Both & 5 & $5 \%$ & 0 & $0 \%$ \\
\hline & Both and any other & 2 & $2 \%$ & 1 & $2 \%$ \\
\hline & Don't know & 6 & $6 \%$ & 5 & $10 \%$ \\
\hline & Not applicable & 26 & $26 \%$ & 5 & $10 \%$ \\
\hline \multirow{6}{*}{$\begin{array}{l}\text { Reason for feeding mothers } \\
\text { Milk only }\end{array}$} & Makes child healthy & 46 & $46 \%$ & 34 & $68 \%$ \\
\hline & Gives Nutrition & 12 & $12 \%$ & 10 & $20 \%$ \\
\hline & Proper Growth and Development & 10 & $10 \%$ & 0 & $0 \%$ \\
\hline & For child's Health and Nutrition & 10 & $10 \%$ & 0 & $0 \%$ \\
\hline & $\begin{array}{l}\text { For child's Health, Growth \& } \\
\text { Development }\end{array}$ & 1 & $1 \%$ & 0 & $0 \%$ \\
\hline & Don't know & 21 & $21 \%$ & 6 & $12 \%$ \\
\hline \multirow{4}{*}{$\begin{array}{l}\text { Period for exclusive breast } \\
\text { Feeding }\end{array}$} & Till 6 months & 71 & $71 \%$ & 49 & $98 \%$ \\
\hline & 4-5 months & 6 & $6 \%$ & 0 & $0 \%$ \\
\hline & Any other & 8 & $8 \%$ & 1 & $2 \%$ \\
\hline & Don’t Know & 15 & $15 \%$ & 0 & $0 \%$ \\
\hline \multirow{3}{*}{$\begin{array}{c}\text { Should water be given to } \\
\text { The child }\end{array}$} & Yes & 21 & $21 \%$ & 17 & $34 \%$ \\
\hline & No & 68 & $68 \%$ & 26 & $52 \%$ \\
\hline & Don’t know & 11 & $11 \%$ & 7 & $14 \%$ \\
\hline \multirow[t]{3}{*}{ If yes, Why } & Child gets thirsty & 14 & $14 \%$ & 2 & $4 \%$ \\
\hline & Don’t know & 10 & $10 \%$ & 15 & $30 \%$ \\
\hline & Not applicable & 76 & $76 \%$ & 33 & $66 \%$ \\
\hline \multirow[t]{2}{*}{ If no, Why } & Mothers milk is enough & 41 & $41 \%$ & 23 & $46 \%$ \\
\hline & Doctor said & 1 & $1 \%$ & 0 & $0 \%$ \\
\hline
\end{tabular}




\begin{tabular}{|c|l|c|c|c|c|}
\hline \multirow{4}{*}{$\begin{array}{c}\text { Meaning of complementary } \\
\text { food }\end{array}$} & Infection & 2 & $2 \%$ & 0 & $0 \%$ \\
\cline { 2 - 5 } & Don't know & 29 & $29 \%$ & 3 & $6 \%$ \\
\cline { 2 - 5 } & Not applicable & 27 & $27 \%$ & 24 & $48 \%$ \\
\hline & $\begin{array}{l}\text { After the completion of 6 months } \\
\text { when the child is started giving food } \\
\text { prepared at home or at AWC }\end{array}$ & 57 & $57 \%$ & 47 & $94 \%$ \\
\cline { 2 - 5 } & Any other & 19 & $19 \%$ & 1 & $2 \%$ \\
\cline { 2 - 6 } & Don't know & 24 & $24 \%$ & 2 & $4 \%$ \\
\hline \multirow{2}{*}{$\begin{array}{c}\text { Age for Giving } \\
\text { complementary food to the } \\
\text { child }\end{array}$} & After completion of 6 months & 79 & $79 \%$ & 48 & $96 \%$ \\
\cline { 2 - 6 } & Any other & 3 & $3 \%$ & 2 & $4 \%$ \\
\cline { 2 - 6 } & Don't know & 18 & $18 \%$ & 0 & $0 \%$ \\
\hline
\end{tabular}

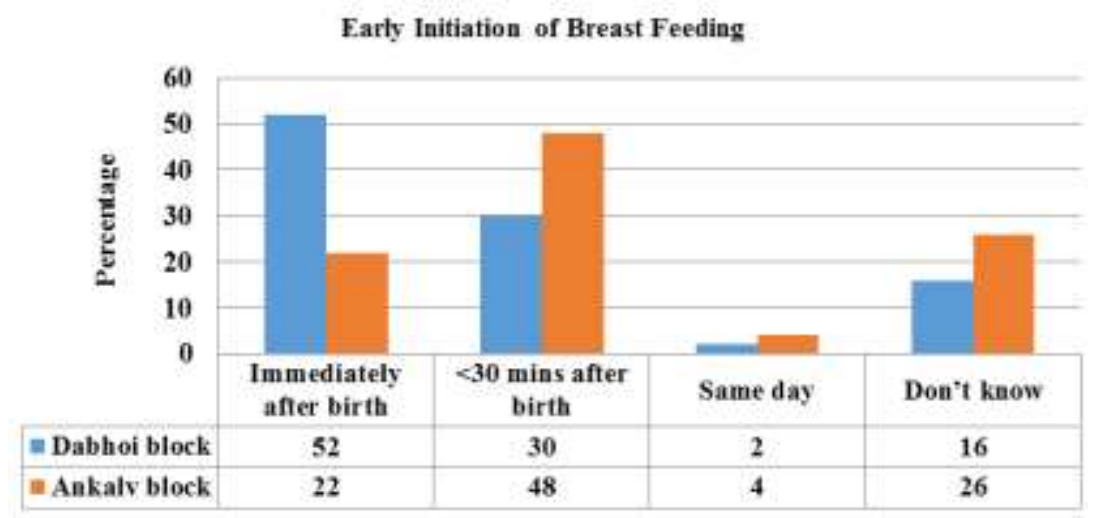

Fig. 3: Knowledge about early initiation of Breast feeding, colostrumand complementary food

Colostrum Feeding

"Dabhoi block $=$ Ankalv block
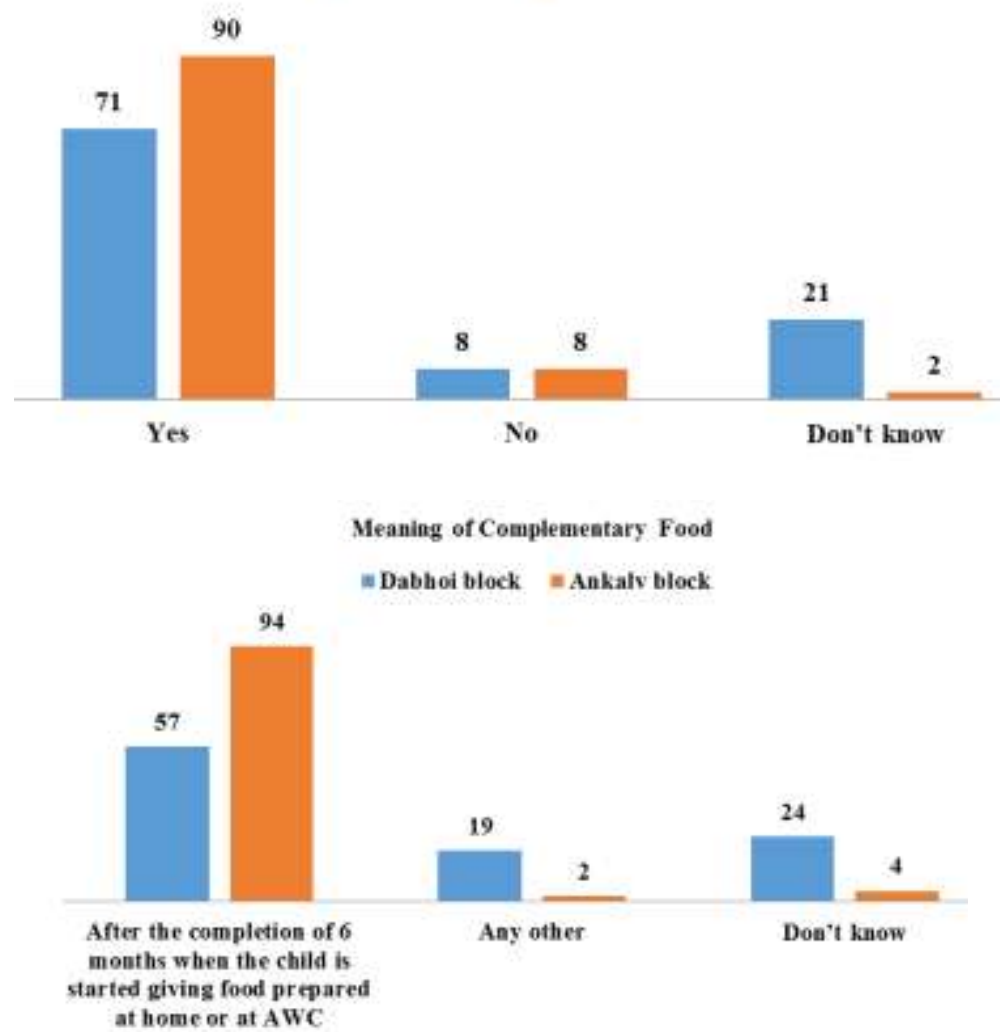
Majority of the women were aware about giving the mother's milk as a first fed to the child. Reasons for giving colostrum was either for improving child's immunity or making child healthy in experimental group $61 \%$ and $78 \%$ in control group. With respect to reasons for giving mothers breast milk only $46 \%$ of the women opined that it is good for child's health in experimental group as compared to $68 \%$ in control group. Most of the women had knowledge of exclusive breast feeding in both the group. Sixty eight percent of pregnant women had a correct knowledge for not giving water to the new born in experimental group as compared to 52\% in control group. Women opined that the child gets thirsty in experimental group $(14 \%)$ and in control group (4\%). With reference to correct IYCF practices, as seen in Fig. $382 \%$ of pregnant womenfrom Dabhoi had correct knowledge about early initiation of breast feeding which is immediately after the birth as compared to $70 \%$ in Anklav group. Ninety percent of pregnant women in Anklavgroup had correct knowledge of giving colostrum to new born as compared to $71 \%$ in Dabhoi groupIt was found that $94 \%$ of pregnant women had correct knowledge about the meaning of complementary feeding in control group against $57 \%$ in experimental group. Ninety six percent of women in Anklavgroup could answer correct age of introducing complementary food as compared to $79 \%$ in Dabhoigroup. As shown in table 3 Knowledge about Anemia

Table 3: Knowledge about Anemia

\begin{tabular}{|c|c|c|c|c|c|}
\hline \multirow{2}{*}{\multicolumn{2}{|c|}{ Particulars }} & \multicolumn{2}{|c|}{ Dabhoi N=100 } & \multicolumn{2}{|c|}{ Anklav N =50 } \\
\hline & & \multirow{2}{*}{$\begin{array}{c}\mathrm{n} \\
33\end{array}$} & \multirow{2}{*}{$\begin{array}{c}\% \\
33 \%\end{array}$} & \multirow{2}{*}{$\begin{array}{c}\mathrm{n} \\
36\end{array}$} & \multirow{2}{*}{$\frac{\%}{72 \%}$} \\
\hline Heard the term anemia & Yes & & & & \\
\hline & No & 67 & $67 \%$ & 14 & $28 \%$ \\
\hline \multirow{6}{*}{ If yes, what } & Pale Blood & 6 & $6 \%$ & 17 & $34 \%$ \\
\hline & Low $\mathrm{Hb}$ & 20 & $20 \%$ & 19 & $38 \%$ \\
\hline & Pale Blood, Low $\mathrm{Hb}$ & 3 & $3 \%$ & 0 & $0 \%$ \\
\hline & Any other & 1 & $1 \%$ & 0 & $0 \%$ \\
\hline & Don’t know & 3 & $3 \%$ & 0 & $0 \%$ \\
\hline & Not applicable & 67 & $67 \%$ & 14 & $28 \%$ \\
\hline \multirow{8}{*}{ Signs of anemia } & Pale eyes, nails, tongue & 6 & $6 \%$ & 0 & $0 \%$ \\
\hline & Pale body & 8 & $8 \%$ & 10 & $20 \%$ \\
\hline & Breathlessness & 6 & $6 \%$ & 2 & $4 \%$ \\
\hline & No energy to do work & 14 & $14 \%$ & 3 & $6 \%$ \\
\hline & $\begin{array}{l}\text { Pale eyes, nails, tongue \& No } \\
\text { energy to do work }\end{array}$ & 7 & $7 \%$ & 0 & $0 \%$ \\
\hline & Pale body \& Breathlessness & 4 & $4 \%$ & 0 & $0 \%$ \\
\hline & Breathlessness, No energy to work & 0 & $0 \%$ & 27 & $54 \%$ \\
\hline & Don’t know & 55 & $55 \%$ & 8 & $16 \%$ \\
\hline \multirow[t]{9}{*}{ Consequences of anemia } & Low birth weight baby & 17 & $17 \%$ & 36 & $72 \%$ \\
\hline & Miscarriages/Abortions & 7 & $7 \%$ & 0 & $0 \%$ \\
\hline & Growth retardation & 4 & $4 \%$ & 1 & $2 \%$ \\
\hline & Difficult labor & 1 & $1 \%$ & 1 & $2 \%$ \\
\hline & Death of mother or child & 7 & $7 \%$ & 0 & $0 \%$ \\
\hline & LBW, Miscarriage /Abortions & 2 & $2 \%$ & 0 & $0 \%$ \\
\hline & LBW \& Growth retardation & 4 & $4 \%$ & 0 & $0 \%$ \\
\hline & Any other & 8 & $8 \%$ & 0 & $0 \%$ \\
\hline & Don't know & 50 & $50 \%$ & 12 & $24 \%$ \\
\hline \multirow[t]{6}{*}{ Prevention of Anemia } & Glv's & 18 & $18 \%$ & 1 & $2 \%$ \\
\hline & Citrus fruits & 17 & $17 \%$ & 3 & $6 \%$ \\
\hline & IFA tablets & 5 & $5 \%$ & 1 & $2 \%$ \\
\hline & Glv's\& Fruits & 9 & $9 \%$ & 30 & $60 \%$ \\
\hline & Any other & 3 & $3 \%$ & 7 & $14 \%$ \\
\hline & Don't know & 48 & $48 \%$ & 8 & $16 \%$ \\
\hline
\end{tabular}

As depicted in Table 3, pregnant women who had heard the term anemia was 72\% in Anklavgroup and 33\% in Dabhoigroup. Knowledge regarding low $\mathrm{Hb}$ was 38\% in Anklavgroup against 20\% in Dabhoi group. Knowledge about signs and symptoms of anemia was poor in both the groups however $72 \%$ in both the groups could answer low birth weight babies as one of the consequences of Anemia. Again knowledge about preventive measure about anemia was poor in Dabhoi group as compared to Anklavgroup as shown in Fig. 4 


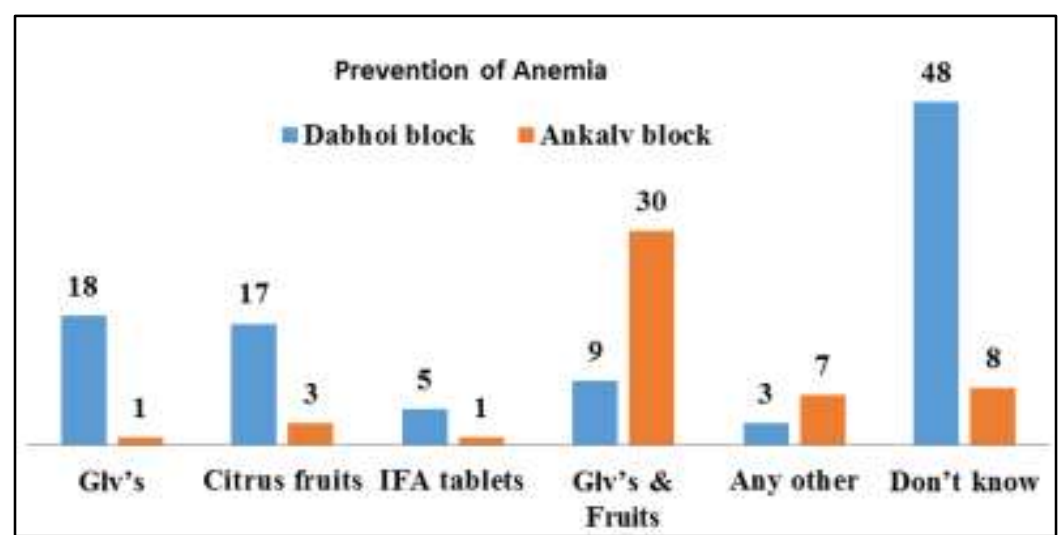

Fig. 4 Knowledge about prevention of anemia

\section{Family Planning Method}

Information was also elicited on spacing between two children and family planning methods which is presented in Table 1.4 Nearly $30 \%$ of pregnant women in both the groups had knowledge about the family planning method used for women like Pills, Copper T and sterilization. The knowledge about the contraceptives method used for man was better among women in Anklav group as compared to Dabhoi group. It was revealed that majority of the women in both the group had correct knowledge about the gap between two children (Fig. 6)

Table 4: Knowledge about family planning method

\begin{tabular}{|l|l|c|c|c|c|}
\hline \multicolumn{2}{|c|}{ Particulars } & \multicolumn{3}{c|}{ Dabhoi N=100 } & Anklav N=50 \\
\cline { 3 - 6 } Gap between 2 children & 3 Years & 70 & $70 \%$ & 42 & $84 \%$ \\
\cline { 2 - 6 } & Any other & 12 & $12 \%$ & 4 & $8 \%$ \\
\cline { 2 - 6 } & Don't know & 18 & $18 \%$ & 4 & $8 \%$ \\
\hline \multirow{5}{*}{ Family planning method for women } & Pills, Copper T, Sterilization & 22 & $22 \%$ & 17 & $34 \%$ \\
\cline { 2 - 6 } & Pills, Copper T & 35 & $35 \%$ & 4 & $8 \%$ \\
\cline { 2 - 6 } & Pills & 0 & $0 \%$ & 13 & $26 \%$ \\
\cline { 2 - 6 } & Copper T & 0 & $0 \%$ & 5 & $10 \%$ \\
\cline { 2 - 6 } & Don't know & 43 & $43 \%$ & 11 & $22 \%$ \\
\hline \multirow{5}{*}{ Family planning method for men } & Condom & 26 & $26 \%$ & 21 & $42 \%$ \\
\cline { 2 - 6 } & Sterilization & 0 & $0 \%$ & 13 & $26 \%$ \\
\cline { 2 - 6 } & Condom, Sterilization & 18 & $18 \%$ & 7 & $14 \%$ \\
\cline { 2 - 6 } & Don't know & 56 & $56 \%$ & 9 & $18 \%$ \\
\hline
\end{tabular}

In the present study, knowledge of pregnant women in the area of basic nutrition, health, anemia and IYCN practices requires improvement to achieve targets of Rashtriya Poshan Abhiyan. In line of current findings, Mohiteet et. $\mathrm{al}^{3}$ in 2012 concluded that knowledge of breast feeding among primigravida mothers attending ANC clinic was of fair in quality.

Gyampoh,et.al (2013) ${ }^{1}$ recommended that although most mothers were knowledgeable about recommendations, feeding practices were suboptimal, especially complementary feeding. Growth Monitoring Promotion exposure was associated with feeding knowledge only among mothers with children less than 6 months. Strengthening of feeding counselling focused on children above 6 months is recommended.

Henry Wamani et.al in ${ }^{2}$ (2005) concluded that, Attention should focus on socio-economic empowerment especially education of the girl child, discouraging use of pre-lacteals, promoting use of oil to increase energy content of complementary food and the timeliness of complementary feeding so as to optimise the benefits of breastfeeding and complementary feedingalso, Sima Roy, Aparajita Dasgupta, and Bobby Pal (2009) ${ }^{4}$ concluded that Infant feeding practices in the community are strongly influenced by what people know, think, and believe about these issues. They are also strongly affected by social circumstances, economic factors, and other forces beyond an individual's intention and ideas. Effective communication for behavioural change should therefore be the prime objective for ensuring optimal infant feeding.

\section{Conclusion}

It can be concluded that knowledge about various aspects of health and nutrition aspects needs improvement and should be reinforced on village health and sanitation days to antenatal mothers and women of reproductive age group. 


\section{Acknowledgement}

The study was partially supported by UGC DSA SAP III of the department of Foods and Nutrition, MSU. Also would like to acknowledge District administration Team of Vadodara district.

\section{Conflict of Interest: None.}

\section{References}

1. Gyampoh. sementic scholars.org

2. Henry Wamani Anne NordrehaugÅstrøm Stefan Peterson Thorkild Tylleskär James K. Tumwine, Infant and Young Child Feeding in Western Uganda: Knowledge, Practices and Socio-economic Correlates. J Trop Pediatr 2005;51(6).
3. Mohite, R V; Mohite, V R; Kakade, S V. Knowledge of breast feeding among primigravida mothers, Bangladesh J Med Sci 2012;11(4)

4. Sima Roy, Aparajita Dasgupta, Bobby Pal, Feeding Practices of Children in an Urban Slum of Kolkata, Indian J Community Med 2009;34(4):362-3.

5. Role of Maternal Nutrition and adherence to RDA on pregnancy outcomes http://vikaspedia.in/health/nutrition/dietary-guidelines-1

6. NITI Aayog National Nutrition Strategy Government Of Indiahttps://niti.gov.in/writereaddata/files/document_publication/Nu tritionStrategyBooklet.pdf

How to cite this article: Gandhi H, Shah M. Identifying knowledge gaps about health and nutrition among rural pregnant mothers from 2 districts of Gujarat. J Nutr Metab Health Sci 2019;2(2):51-7. 